\title{
Effect of mesenchymal stem cells on movement and urination of rats with spinal cord injury
}

\section{Efeitos da aplicação das células-tronco mesenquimais sobre a locomoção e micção de ratos submetidos à lesão medular}

\author{
Alexandra Justino da Silva ${ }^{1}$; José Ademar Villanova Junior ${ }^{2 *}$; Letícia Fracaro"; \\ Carmen Lúcia Kuniyoshi Rebelatto ${ }^{3}$; Fabiane Barchiki'; \\ Sérgio Adriane Bezerra de Moura ${ }^{4}$; Alejandro Correa Dominguez; \\ Ana Paula Resseti Abud ${ }^{5}$; Rosângela Locatelli-Dittrich ${ }^{6}$; \\ Paulo Roberto Slud Brofman²; Juliany Gomes Quitzan ${ }^{7}$
}

\begin{abstract}
Cell therapy has frequently been reported as a possible treatment for spinal trauma in humans and animals; however, without pharmacologically curative action on damage from the primary lesion. In this study, we evaluated the effect of administering human adipose-derived stem cells (hADSC) in rats after spinal cord injury. The hADSC were used between the third and fifth passages and a proportion of cells were transduced for screening in vivo after transplantation. Spinal cord injury was induced with a Fogarty catheter no. 3 inserted into the epidural space with a cuff located at T8 and filled with $80-\mu \mathrm{L}$ saline for 5 min. The control group $\mathrm{A}(\mathrm{n}=12)$ received culture medium $(50 \mu \mathrm{L})$ and group $\mathrm{B}$ $(\mathrm{n}=12)$ received hADSC $\left(1.2 \times 10^{6}\right)$ at 7 and 14 days post-injury, in the tail vein. Emptying of the bladder by massage was performed daily for 3 months. Evaluation of functional motor activity was performed daily until 3 months post-injury using the Basso-Beattie-Bresnahan scale. Subsequently, the animals were euthanized and histological analysis of the urinary bladder and spinal cord was performed. Bioluminescence analysis revealed hADSC at the application site and lungs. There was improvement of urinary bladder function in $83.3 \%$ animals in group B and $16.66 \%$ animals in group A. The analysis of functional motor activity and histology of the spinal cord and urinary bladder demonstrated no significant difference between groups A and B. The results indicate that transplanted hADSC improved urinary function via a telecrine mechanism, namely action at a distance.
\end{abstract}

Key words: Spinal cord injury, paraplegia, urinary incontinence, cell therapy, bioluminescence

\section{Resumo}

A terapia celular tem sido reportada como possibilidade de tratamento para os traumas medulares, frequentes em pessoas e em animais, e que não apresentam cura farmacológica para danos advindos da

\footnotetext{
${ }^{1}$ Pesquisadoras, Mestres, Pontifícia Universidade Católica do Paraná, PUCPR, Curitiba, PR, Brasil. E-mail: ale.veterinária@ hotmail.com; letícia.fracaro@pucpr.br; fabiane.barchiki@pucpr.br

${ }^{2}$ Profs. Drs., PUCPR, Curitiba, PR, Brasil. E-mail: jose.villanova@pucpr.br; paulo.brofman@pucpr.br

${ }^{3}$ Pesquisadora, Dr ${ }^{\mathrm{a}}$, PUCPR, Curitiba, PR, Brasil. E-mail: carmen.rebelatto@pucpr.br

${ }^{4}$ Prof. Dr., Universidade Federal do Rio Grande do Norte, UFRN, Natal, RN, Brasil. E-mail: sergioabm@gmail.com

${ }^{5}$ Pesquisadores, Instituto Carlos Chagas, ICC, Curitiba, PR, Brasil. E-mail: alejandro@tecpar.br; ana-abud@hotmail.com

${ }^{6}$ Prof $^{\mathrm{a}} \mathrm{Dr}^{\mathrm{a}}$, UFPR, Curitiba, PR, Brasil. E-mail: roslocdi@ufpr.br

${ }^{7}$ Prof $^{\mathrm{a}} \mathrm{Dr}^{\mathrm{a}}$, Universidade Estadual Paulista, UNESP, Botucatu, SP, Brasil. E-mail: juquitzan@fmvz.unesp.br

* Author for correspondence
} 
lesão primária. Foram avaliados os efeitos da aplicação de células-tronco derivadas do tecido adiposo humano (hADSC) em ratos Wistar após lesão medular. As hADSC foram cultivadas, utilizadas entre a terceira e quinta passagens e parte delas foi transduzida para o rastreamento in vivo após o transplante. A lesão medular foi realizada com cateter de Fogarty $n^{\circ} .3$, introduzido no espaço epidural, com cuff localizado em T8 e preenchido com $80 \mu \mathrm{L}$ de solução salina, por 5 minutos. Os animais do grupo controle $(\mathrm{A}, \mathrm{n}=12)$ receberam aplicações de meio de cultura $(50 \mu \mathrm{L})$ e o grupo $\mathrm{B}(\mathrm{n}=12)$ recebeu duas aplicações de hADSC $\left(1,2 \times 10^{6}\right)$, sete e 14 dias pós-lesão, ambas na veia da cauda. O esvaziamento vesical, por massagem, foi efetuado diariamente, durante três meses. As avaliações motoras foram repetidas, diariamente, até três meses pós-lesão, utilizando a escala Basso-Beattie-Bresneham. Após este período os animais foram submetidos à eutanásia e foram realizadas análises histológicas de bexiga urinária e medula espinhal. As análises de bioluminescência revelaram hADSC no local da aplicação e nos pulmões. Houve melhora da função da bexiga urinária em 83,3\% dos animais do grupo B e 16,66\% dos animais do grupo A. A análise das avaliações motoras e histológicas das medulas espinhais e bexigas urinárias não demonstrou diferenças significativas entre os grupos A e B. Os resultados indicam que as hADSC transplantadas influenciaram a micção, de forma benéfica, por um mecanismo de ação à distância, telécrino.

Palavras-chave: Lesão medular, paraplegia, incontinência urinária, terapia celular, bioluminescência

\section{Introduction}

The main cause of neurological consultation in companion animals is spinal cord injury (GREEN; BOSCO, 2008), the severity of which depends on the speed, degree, and duration of compression (SOUZA; ESCOBAR; DEL BEL, 2009).

Neurological deficit as a result of acute spinal cord injury can result from mechanical damage (primary lesion) to neuronal pathways immediately after the trauma and as a result of posterior tissue injury (secondary) that occurs over a period of minutes to days after the primary lesion. These late lesions trigger a cascade of systemic, destructive, local events at the cellular level, resulting in ischemia, hypoxia, edema, and several biochemical events that are harmful to the spinal cord (OSAKO; AKAMINE; SANTOS, 2008).

While no pharmacological cure for spinal cord injury is currently available (FITZMAURICE, 2011), a promising alternative is regenerative treatment via transplant of mesenchymal stem cells (MSCs) (MEIRELLES; CHAGASTELLES; NARDI, 2006) found in the stroma of various organs and can be obtained from several tissues such as adipose tissue, bone marrow, dental pulp, tendons, umbilical cord blood, and placenta (SOARES, 2006). They possess the ability to differentiate and produce any cell type required for the repair process (PITTENGER et al., 1999). According to Caplan (2009), they play a role in the maintenance and renewal of adult mesenchymal tissue. Besides the ability to differentiate, these cells exhibit paracrine effects via secretion of growth factors, cytokines, anti-fibrotic or angiogenic mediators (DJOUAD et al. 2009).

The transplanted cells can be tracked after their transduction with specific vectors and assessed by in vivo bioluminescence (ROET; EGGERS; VERHAAGEN, 2012). The use of human stem cells in rats with spinal cord injury revealed migration of cells to the injured site (PAL et al., 2010) and reduction of the inflammatory reaction (PARK et al., 2010).

In this study, we aimed to monitor the path of stem cells derived from human adipose tissue (hADSC) administered into the tail vein to assess the effect on urinary function and locomotion after transplantation, as well as histology of the urinary bladder and spinal cord of rats with spinal trauma.

\section{Material and Methods}

\section{Animals}

We used 26 Wistar rats, an average of 30 weeks old and weighing between 250 and $300 \mathrm{~g}$. The 
animals were kept in cages ( 2 or 3 animals in each cage) and provided water and food ad libitum under controlled conditions of temperature $\left(22 \pm 2^{\circ} \mathrm{C}\right)$, humidity $(45 \% \pm 15 \%)$, and ventilation (upper and lower exhausts) with a $12 / 12 \mathrm{~h}$ light cycle (fluorescent lamp). The animals were divided into 2 groups: group $\mathrm{A}$, control $(\mathrm{n}=12)$, with transplanted culture medium, and group $\mathrm{B}(\mathrm{n}=12)$ transplanted twice with hADSC, at 7 and 14 days after injury.

\section{Isolation and cultivation of hADSC}

Approximately $100-\mathrm{mL}$ adipose tissue was obtained from 3 donors who underwent bariatric surgery and dermolipectomy. The hADSC were isolated by enzymatic digestion method. The adipose tissue was washed with phosphate saline solution, macerated, and digested with $1 \mathrm{mg} / \mathrm{mL}$ type I collagenase $\left(30 \mathrm{~min}\right.$ at $\left.37^{\circ} \mathrm{C}\right)$ with constant stirring, followed by filtration ( 40 - and $100-\mu \mathrm{m}$ pore filters). Cell suspension was centrifuged $(800 \times g$; $10 \mathrm{~min}$ ) and the contaminating erythrocytes were removed after lysis with a buffer at $\mathrm{pH}$ 7.3.

Cells were washed and cultured at a density of $1 \times 10^{5}$ cells $/ \mathrm{cm}^{2}$ in $\mathrm{T} 75$ culture flasks with DMEM-F12 supplemented with 10\% fetal bovine serum (FBS), penicillin (100 units $/ \mathrm{mL})$, and streptomycin $(100 \mu \mathrm{g} / \mathrm{mL})$. The medium was changed 3 days after initial plating. The culture medium was replaced twice weekly. When the cultures reached approximately $80 \%$ to $90 \%$ confluence, the cells were dissociated using $0.25 \%$ trypsin/EDTA and re-plated (passage 1).

\section{Viability $h A D S C$}

Cell viability was assessed using the vital dye Trypan blue, which stains dead cells blue. For this evaluation, $10 \mu \mathrm{L}$ Trypan blue mixed with 50 $\mu \mathrm{L}$ hADSC was added to each well of a 96-well plate. After homogenization, $10 \mathrm{~L}$ was placed in a Neubauer chamber to count live and dead cells. hADSC were used between the third and fifth passages. The characterization of cultivated hADSC was previously reported by Rebelatto et al. (2008).

\section{Transduction of hADSC}

For monitoring bioluminescence in vivo after transplantation of hADSC, HEK 293 (Human Embryonic Kidney 293 cells) cells were transfected with pMD2.G, pCMV_dr8.91, and pMSCV_Luc2 T2A vectors using Lipofectamine 2000 and were maintained in culture for 3 days. The supernatant containing the viral particles was collected, filtered using a $0.22 \mu \mathrm{m}$ filter and ultracentrifuged $(75,000 \times \mathrm{g}$; $1 \mathrm{~h} 30 \mathrm{~min})$. The pellets were resuspended in phosphate buffered saline (PBS) /bovine serum albumin (BSA) $1 \%$, distributed in $40-\mu \mathrm{L}$ aliquots, and stored at $-80^{\circ} \mathrm{C}$. The hADSC were transduced with the supernatants containing virus particles and $10 \mathrm{mg} / \mu \mathrm{L}$ hexadimethrine bromide. The medium used for cell transduction was changed every 24 h over 3 days. After the first 24 h, puromycin was added for selection of transduced cells in a final concentration of $10 \mathrm{mM}$. Luciferase expression was observed using IVIS Lumina Imaging System II (Caliper Life Sciences).

\section{Evaluation of hADSC transduction by} bioluminescence imaging

To determine the bioluminescence of transduced cells, they were plated into 24-well plates at a concentration of 30,000 cells/well in D-Luciferin $(150 \mu \mathrm{g} / \mathrm{mL})$ culture medium. Bioluminescence was measured in the plate in consecutive image series (30-s exposure) for high signal intensity (measured in counts). The total area of a well was the region of interest and quantification of bioluminescence was in photons/sec.

Induction of spinal trauma and post-spinal cord injury care

The animals were anesthetized with ketamine 
(70 $\mathrm{mg} / \mathrm{kg}$; intramuscularly [IM]), xylazine $(10 \mathrm{mg} / \mathrm{kg}$; IM), and atropine sulphate $(0.05 \mathrm{mg} / \mathrm{kg}$; intraperitoneally [IP]). Anesthesia was maintained with isoflurane $4 \%$ anesthetic circuit with $100 \%$ oxygen. After trichotomy and antisepsis a 5.0$\mathrm{cm}$ incision was made in the dorsal midline, with reference of the eighth thoracic vertebra (T8) to the first lumbar vertebra (L1), subcutaneous tissue was incised, followed by subperiosteal removal of the paraspinal musculature (surgical scalpel 11).

Spinal cord injury was induced after laminectomy at T10 and introduction of Fogarty catheter no. 3 into the epidural space, the cuff located in the T8 was filled ( $80 \mu \mathrm{l}$ saline solution; $5 \mathrm{~min}$ ).

The approximation of muscle was performed with 4-0 Vicry ${ }^{\circledR}$ line (Ford suture anchor pattern) followed by a skin graft (3-0 monofilament nylon), using the same suture pattern. At the end of the surgical procedure enrofloxacin $(10 \mathrm{mg} / \mathrm{kg}$ IM sid) was administered for 3 days. Pre and post-operative furosemide injections (4 $\mathrm{mg} / \mathrm{kg}$; subcutaneous [SC]) were administered to minimize neurogenic pulmonary edema due to injury.

After recovery from anesthesia, analgesia with morphine ( $5 \mathrm{mg} / \mathrm{kg}$; $\mathrm{SC}$; qid) was administered for 3 days.

\section{Post-injury motor and urinary function assessments}

Only those animals that were healthy prior to inducing the spinal injury and that presented with post- injury paraplegia and urinary incontinence were included in the experiment.

Voiding evaluations were performed via manual bladder emptying performed daily, on average every 6 hours for 3 months. We evaluated the presence of hematuria, incontinence or retention with overflow incontinence due to sagging of the bladder sphincter.

Performance test were carried out daily for 90 days in a plastic box without barriers, following the BBB scale (BASSO, BEATIE; BRESNAHAN, 1995), which varies between 0 and 21 points and reflects the animal locomotor conditions, in which a score of 0 refers to total paralysis of the hind limbs, while 21 reflects regular locomotor activity.

\section{Transplantation of $h A D S C$}

Animals in both groups received 2 transplants, one at 7 days and the other at 14 days post-injury. Rats in the control group $(n=12)$ were transplanted with $50-\mu \mathrm{L}$ culture medium and animals in group B $(\mathrm{n}=12)$, were transplanted with $50 \mu \mathrm{L}$ cell suspension $\left(1.2 \times 10^{6} \mathrm{hADSC}\right)$.

hADSC were transplanted via tail vein puncture into rats under anesthesia. The procedure was performed slowly using a Hamilton syringe and after the total volume was delivered, the needle was kept in place for $1 \mathrm{~min}$, to avoid reflux.

\section{In vivo bioluminescence imaging}

After transplantation, the location and survival status of hADSC was assessed by in vivo bioluminescence imaging in group $\mathrm{B}(\mathrm{n}=2)$, where the light intensity was captured via an in vivo imaging system (IVIS ${ }^{\circledR}$ LUMINA II, Caliper Life Sciences). Animals were anesthetized by isoflurane inhalation (4\%) and injected with $150 \mathrm{mg} / \mathrm{kg}$ D-luciferin intraperitoneally. They were placed in a dark room in the dorsal position and images were captured by a high sensitivity camera $(12.7 \times 12.7$ $\mathrm{cm}$ capture field). A series of images were acquired to obtain the maximum peak bioluminescence (measured in counts). Quantification was measured in photons/second using LIVING IMAGE software (version 4.5) (Xenogen). The signal strength of the transplanted cells was assessed on days 7, 8, 14, 15, and 30 after injury.

Euthanasia and histological analyses of the urinary bladder and spinal cord

On the $90^{\text {th }}$ day post-spinal cord injury, animals in groups A and B were euthanized. After anesthesia 
and cannulation of the left ventricle apex with a fine needle was performed, a small incision was made in the right atrium and infused with $150-\mathrm{mL}$ isotonic saline solution using an infusion pump, followed by $350-\mathrm{mL}$ refrigerated $4 \%$ paraformaldehyde.

After euthanasia, histological slides of the urinary bladder (cervix and bladder body) and the epicenter of the spinal lesion were prepared.

Two histological slides of each bladder were made; one was stained with hematoxylin-eosin (HE) for comprehensive assessment of tissue sections, while the other by Masson's trichrome (MT) for evaluation of existing collagen fibers. For histological evaluation of the spinal cord, HE staining was used.

Images of the histological slides were scanned using DP2-BSW software OLYMPUS, while wall thickness of the bladder was measured using IMAGE-PRO PLUS software. A total of 8 bladder samples were analyzed, 4 of the bladder neck (region A) and another 4 of the body (B region).

The same software was used in each histological image of the spinal cord, for measurement of spinal cord area.

We conducted a qualitative assessment of the bladder using criteria such as inflammation and bleeding in HE stain and collagen deposition in MT stain. The parameters used were as those reported previously by Maia et al. (2006).

\section{Statistical analysis}

The result obtained by labeling stem cells with IVIS Lumina device was evaluated and presented in the form of descriptive statistics.

The motor and bonding data between groups were evaluated by Kruskal-Wallis test and Dunn's post-test. Motor function and incontinence data were evaluated by chi-square test. The bladder thickness data were analyzed by ANOVA (one-way) followed by the Bonferroni test. The level of significance was $5 \%(p=0.05)$. All calculations were performed using the statistical software GraphPad Prism Version 5.00 for Windows.

\section{Results}

\section{Viability of $h A D S C$}

The average viability of the cells used in the first and second transplantation was $97.5 \%$ and $98.7 \%$, respectively.

\section{Mortality during and after spinal cord injury}

A mortality rate of $38.46 \%$ was observed and the main causes were neurogenic pulmonary edema $(26.92 \% ; n=7)$ and urinary retention $(11.53 \% ; n=3)$.

\section{Evaluation of urination pattern}

After the induction of spinal cord injury, 100\% of the animals $(n=24)$ showed urinary retention, with $84.61 \%$ showing macroscopic hematuria $(\mathrm{n}=22)$. In $11.53 \%$ of operated rats $(\mathrm{n}=3)$, retention was unresponsive to bladder massage. After attempting bladder emptying by cystocentesis, the animals died.

Urine output was not measured, hence some animals had spontaneous bladder emptying, which was empty at the time of bladder massage. This particular feature was observed in $83.33 \%$ of the animals $(n=10)$ from Group B, an average of 8 days after the second hADSC dose, and $16.66 \%(n=2)$ in Group A. Thus, animals in group B had different and superior return urination as compared to group A $(p=0.01)$. The remaining animals in both groups showed retention incontinence, emptying being necessary during the study period.

\section{Motor assessment}

A score of zero on the BBB scale was obtained, meaning no observable movement in the pelvic 
region in groups $\mathrm{A}$ and $\mathrm{B}$.

\section{In vivo evaluation of transplanted $h A D S C$}

In vivo evaluation was performed in 2 animals, of which 1 died, hence the assessment was done only on the day of the first transplant (7 days post-injury). In this animal, the cells remained at the site of transplantation. In the other animal, 5 evaluations were performed. On the $7^{\text {th }}$ day after injury, cells were observed at the site of transplantation (Figure 1) and in lungs (Figure 2). On the $8^{\text {th }}, 14^{\text {th }}$ and $15^{\text {th }}$ day post-injury, cells were located at the site of transplantation. At 30 days, post-lesion cells were not visible. At this point, the animal was euthanized, the injured spinal cord segment was immediately removed, placed on a plate and an evaluation was performed using IVIS Lumina II (Figure 1). In this evaluation as well, cells were not visible (Figure 1).

Figure 1. Bioluminescence signal of transduced hADSC transplanted into the tail vein. The site of transplantation shows presence of cells. A higher bioluminescence signal was observed on post-injury days 14 and 15 , according to the colorimetric bar (image right side). No cells were visualized at 30 days post-injury of the spinal cord segment.

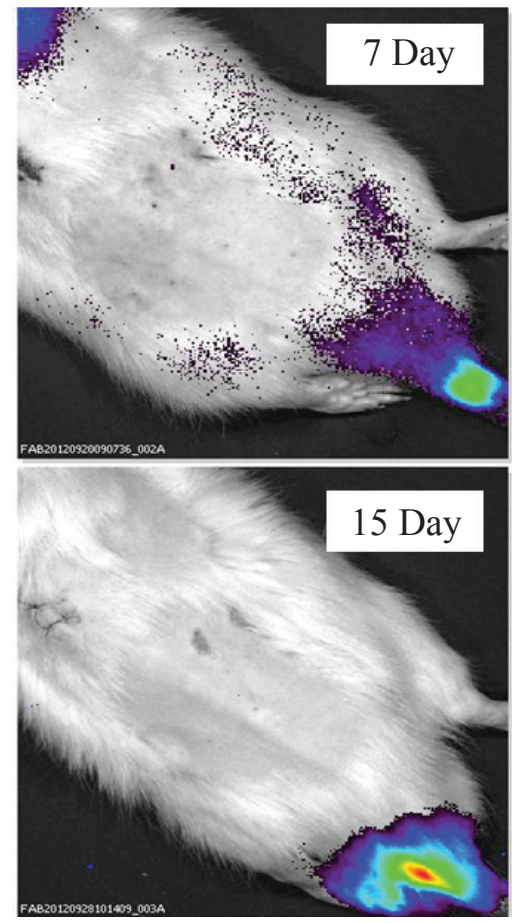

Source: Elaboration of the authors.
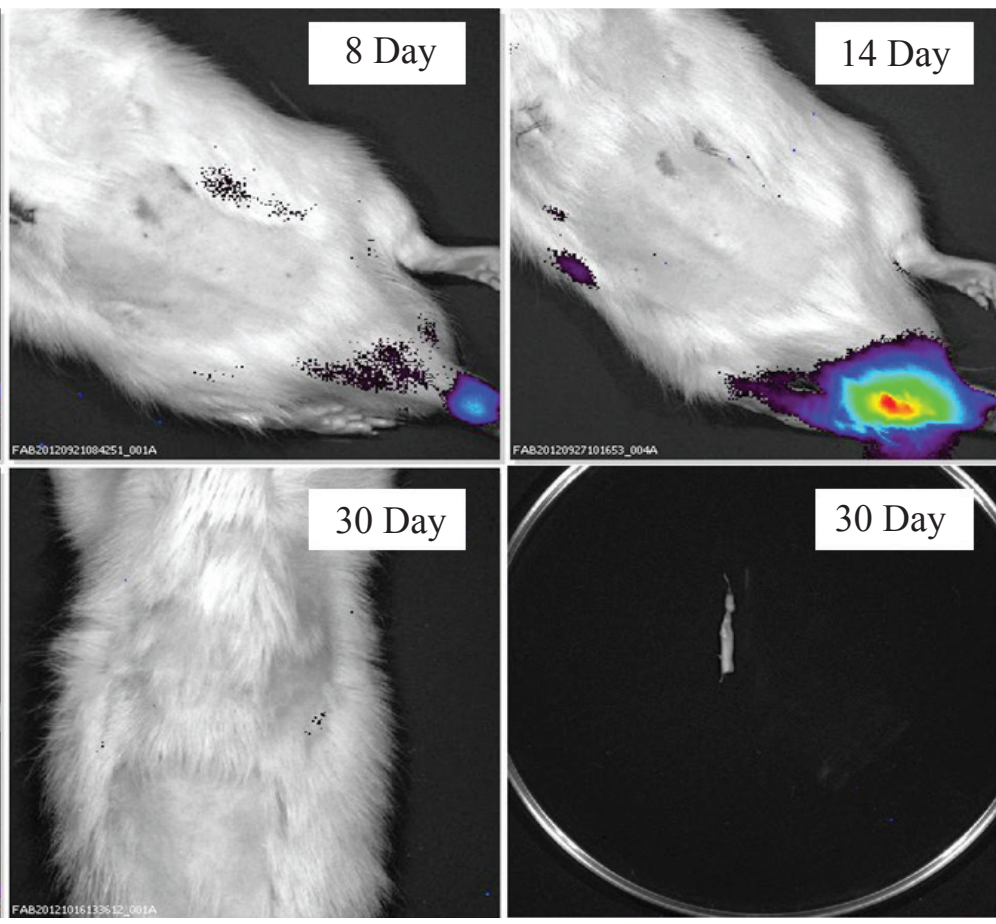
Figure 2. Bioluminescence signal of transduced hADSC transplanted into the tail vein and located in the lungs on day 7 post-injury.

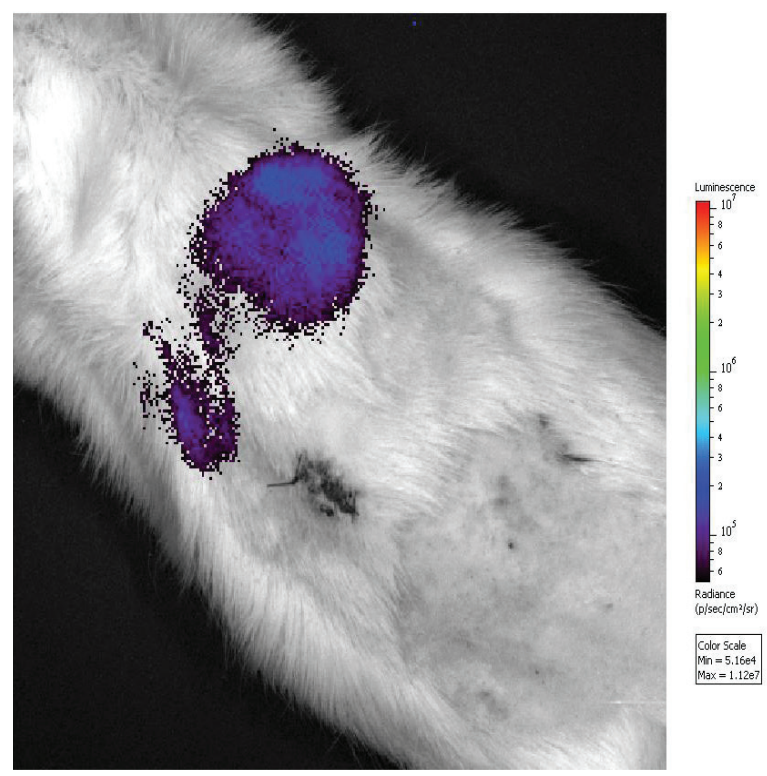

Source: Elaboration of the authors.

Histological analysis of spinal cord and urinary bladder samples

The bone marrow segment analyzed, showed no significant difference between the means of groups $\mathrm{A}(753.43 \mu \mathrm{m})$ and B $(794.31 \mu \mathrm{m})(p=0.77)$.

An average of 8 measurements were taken on each of bladder sections, were evaluated and compared but no difference between groups A and $B(p=0.55)$ were observed. Additionally, no difference between groups A and B was observed in the qualitative evaluation of the bladder samples.

\section{Discussion}

The experimental model of spinal cord injury (SCI) used was similar to that described by Leal Filho et al. (2005), and was demponstrated to be easy to perform, inexpensive, effective, and reproducible. As in studies by Villanova Junior (2013), paraplegia in all animals was used as an inclusion criteria, the catheter balloon filled with $80-\mu \mathrm{L}$ saline solution for 5 min provoked paraplegia without spontaneous and progressive improvement.

Neurogenic pulmonary edema (NPE) occurred in all animals and was the cause of death in $26.92 \%$ $(\mathrm{n}=7)$ animals. Compression by the $80-\mu 1$ solution for $5 \mathrm{~min}$ was the cause of NPE during compression as well as up to $48 \mathrm{~h}$ after SCI. NPE is characterized as protein-rich pulmonary edema, that develops based on hyperactivity of the sympathetic system, also called storm of catecholamines (LEAL FILHO et al., 2005).

To our knowledge, this is the first description of the relationship between age and incidence of NPE, since younger animals, about 20 weeks old, showed edema more frequently than older ones, averaging about 30 weeks. Thus, the condition may be related to lung immaturity and the relatively small diameter of the medullary canal in younger animals. Respiratory support is an important therapeutic aspect in NPE (LEAL FILHO et al., 2005), which is why all animals were kept on oxygen therapy for spinal cord compression and immediately post surgery.

In this study, we used in vitro expanded hADSC, which are hypo-immunogenic because they fail to express HLA class 2 and co-stimulatory molecules, prevent response by direct and indirect $\mathrm{T}$ cells, and induce a local suppressive microenvironment through the production of prostaglandins and interleukins (MONTEIRO; ARGOLO NETO; DEL CARLO, 2010; GNECCHI; DANIELI; CERVIO, 2012). Moreover, Aggarwal and Pittenger (2005) demonstrated that transplantation of MSCs altered the phenotypes of specific immune cells, creating a "tolerogenic" environment. Thus, it is clear that MSCs can be transplanted allogenically without inducing rejection (RYAN et al., 2005).

Several studies have been reported on xenogenic MSCs including studies in dogs by Plotnikov et al. (2007), nude rats by Guest et al. (2008), Wistar rats by Pal et al. (2010), Park et al. (2010), and Villanova Junior (2013), Balb/c mice by Ra et al. (2011), who reported no adverse effects after transplantation and 
no evidence of tumorigenicity.

As previously observed (RA et al., 2011) intravenous application of hADSC was safe, showing no adverse effects such as obstruction of flow or tumorigenic effect.

In this study, evaluation of 2 animals by bioluminescence showed that the cells remained at the application site and in one animal, also migrated into the lungs. Regarding cells identified at the infusion site, the vein may have overflowed at the time of application, causing the cells to remain in the subcutaneous tissue. Vein dissection and phlebotomy may be considered in future studies to prevent this occurrence.

Wang et al. (2012) performed transplantation of mesenchymal stem cells into the tail vein of mice and observed by means of bioluminescence, that cells remained in organs such as the lungs, liver, and spleen for at least 7 days after transplantation. Other authors (GAO et al., 2001; SCHREPFER et al., 2007; ARAUJO, 2013) have also observed that after infusion in this manner, the cells do not aggregate in large numbers to the organ of primary interest, since most are retained in the lung. One hypothesis to justify the retention of these cells in the lungs is the size of cells relative to the diameter of the pulmonary capillaries. Comparisons between different cell diameters and the use of vasodilators demonstrated the retention or release of cells into the arterial blood stream (SCHEREPFER et al., 2007).

Morphometric analysis in this study indicated no significant difference in the lesion area between control animals and those who received hADSC. Similar results were described by Araújo (2013) and Villanova Junior (2013). In contrast, other studies reported a significant reduction in the lesion area, and greater preservation of white matter in animals transplanted with stem cells, indicating the neuroprotective effect of these cells (BAKSHI et al., 2006; URDZIKOVA et al., 2006). Morphological findings cannot be used as the sole criterion for assessing the effect of MSC in compressive spinal cord injury, hence needing more specific analyzes.

Araújo (2013) noted that transplanted stem cells contributed to controlling inflammation after SCI. This reduction in the concentration of macrophages/ microglia $\mathrm{CD} 8^{+}$may have attenuated the deleterious secondary mechanisms caused by inflammation.

It may be noted that all animals in this study had urinary retention after spinal cord compression. Urinary inertia acts as a medium for bacterial growth and detrusor hypertrophy, with consequent deposition of collagen between its fibers (LANDAU et al., 1994), affecting bladder compliance.

To avoid such complications, the animals underwent 4 daily bladder massages. However, unresponsive retention was observed in 11 animals $(53 \% ; n=3)$. In animals that did not respond to the stimulus, cystocentesis was performed that resulted in death, demonstrating that it is not a safe alternative when there is bladder distention in rats.

The low rate of histological changes observed in the comparison of tests performed in the bladders of mice from both groups can be attributed to constant massage for bladder emptying and consequent low residual volume, contributing to the lower rate of infection, hypertrophy and fibrosis.

It was also noted that most animals developed spontaneous bladder emptying during emptybladder massage. This feature was observed in $83 \%$ of animals in group $\mathrm{B}$, on average 8 days after the second dose of hADSC, while only $17 \%$ of the animals in group A had spontaneous vesicle voiding. The remaining animals in both groups had incontinence and the bladder needed emptying throughout the study period. These results indicate that transplantation of hADSC in rats with spinal cord injury may be associated with immunomodulatory and neuroprotective effects, corroborating the results by Araújo (2013), who observed that the application of MSCs intravenously had a beneficial effect on recovery from traumatic spinal cord injury in Wistar rats, as their studies 
revealed attenuation and reactivity of astrocytes and activation of macrophages/microglia in addition to displaying the stem cell mesenchymal ability to stimulate the activation of endogenous neural stem cells in the injured area.

\section{Conclusion}

Spinal cord compression by catheter Fogarty n.3 filled with $80 \mu \mathrm{L}$ saline was effective in producing paraplegia and urinary incontinence in rats, while the major complication observed was neurogenic pulmonary edema.

Our data suggest that transplantation of hADSC may be associated with the recovery of urinary continence in rats subjected to spinal cord injury via a telecrine pathway.

\section{Ethics Committee and Biosafety}

Registration of project in the ethics committee on use of animals: 637

Registration of project in the ethics committee: 04260412.0.0000.0100.

\section{References}

AGGARWAL, S.; PITTENGER, M. F. Human mesenchymal stem cells modulate allogeneic immune cell responses. Blood., Washington, v. 105, n. 4, p. $1815-$ $1822,2005$.

ARAÚJO, M. R. Avaliação histológica e imunofluorescente da lesão compressiva na medula espinhal de ratos Wistar tratados com células-tronco mesenquimais. 2013. Dissertação (Mestrado em Biologia Celular e Estrutural) - Universidade Federal de Viçosa, Viçosa.

BAKSHI, A.; BARSHINGER, A. L.; SWANGER, S. A.; MADHVANI, V.; SHUMSKY, J. S.; NEUHUBER, B.; FISCHER, I. Lumbar puncture delivery of bone marrow stromal cells in spinal cord contusion: a novel method for minimally invasive cell transplantation. Journal of Neurotrauma, Pennsylvania v. 23, n.1, p. 55-65, 2006.

BASSO, D. M.; BEATIE, M.S.; BRESNAHAN, J.C. A sensitive and reliable locomotor rating scale for open field testing in rats. Journal of Neurotrauma, Virginia, v. 12, n. 1, p. 1-21, 1995.

CAPLAN, A. I. Why are MSCs therapeutic? New data: new insight. The Journal of Pathology, Cleveland, v. 217, n. 2, p. 318-324, 2009.

DJOUAD, F.; BOUFFI, C.; GHANNAM, S.; NOEL, D.; JORGENSEN, C. Mesenchymal stem cells: innovate therapeutic tools for reumatic diseases. Nature Reviews Rheumatology, Maryland, v. 5, n. 104, p. 392-399, 2009.

FITZMAURICE, S. N. Neurologia em pequenos animais. Rio de Janeiro: Elsevier, 2011. 332p.

GAO, J.; DENISS, J. E.; SOLCHAGA, L. A.; AWADALLAH, A. S.; GOLDBERG, V. M.; CAPLAN, A. I. Tissue engineered fabrication of an osteochondral composite graft using rat bone marrow-derived mesenchymal stem cells. Tissue Engeenering, Cleveland, v. 7, n.4, p. 363-371. 2001.

GNECCHI, M.; DANIELI, P.; CERVIO, E. Mesenchymal stem cell therapy for heart disease. Vascular Pharmacology, Atlanta, v. 57, n. 1, p. 48-55, 2012.

GREEN, J.; BOSCO, E. Trauma de medula espinhal. In: TELLO, L. H. Trauma em cães e gatos. São Paulo: MedVet Livros, 2008. cap. 14, p. 165-176.

GUEST, J. D.; HERRERA, L.; MARGITICH, I.; OLIVEIRA, M.; MARCILLO, A.; CASAS, C. E. Xenografts of expanded primate olfactory ensheathing glia support transient behavioral recovery that is independent of serotonergic or corticospinal axonal regeneration in nude rats following spinal cord transection. Experimental Neurology, Florida, v. 212, n. 2, p. 261-274, 2008.

LANDAU, E. H.; JAYANTHI, V. R.; CHURCHILL, B. M.; SHAPIRO, E.; GILMOUR, R. F.; KHOURY, A. E.; MACARAK, E. J.; McLORIE, G. A.; STECKLER, R. E.; KOGAN, B. A. Loss of elasticity in dysfunctional bladders: Urodynamic and histochemical correlation. Journal of Urology, Toronto, v. 152, n. 2, p. 702-705, 1994.

LEAL FILHO, M. B.; MORANDIN, R. C.; ALMEIDA, A. R.; CAMBIUCCI, E. C.; KONRADIN, M.; BORGES, G.; GONTIJO, J. A. R. Hemodynamic parameters and neurogenic pulmonary edema following spinal cord injury: an experimental model. Arquivos de Neuropsiquiatria, São Paulo, v. 63, n. 4, p. 990-996, 2005.

MAIA, J. M. A.; CZEKCZKO, N. G.; RIBAS FILHO, J. M.; DIETZ, U. A.; DUCKD, D.; RIBAS, C. A. P. M.; SANTOS, E. A.; BAPTISTELLA, E.; WALLBACH, T. Z.; VALE, J. R.; YAGUSHITA, N. Estudo da cicatrização de suturas na bexiga urinária de ratos com e sem a 
utilização de extrato bruto de Jatropha gossypiifolia L. intraperitoneal. Acta Cirúrgica Brasileira, v. 21, p. 2330, 2006. Suplemento 2.

MEIRELLES, L. C.; CHAGASTELLES, P. C.; NARDI, B. N. Mesenchymal stem cells reside in virtually all post-natal organs and tissues. Journal of Cell Science, London, v. 119, n. 11, p. 2204-2213, 2006.

MONTEIRO, B. S.; ARGOLO NETO, N. M.; DEL CARLO, R. J. Células-tronco mesenquimais. Ciência Rural, Santa Maria, v. 40, n. 1, p. 238-245, 2010.

OSAKO, F. S. U.; AKAMINE, C.; SANTOS, M. M. Emergências neurológicas. In: SANTOS, M. M.; FRAGATA, F. S. Emergências e terapia intensiva veterinária em pequenos animais. São Paulo: Roca, 2008. cap. 23, p. 317-329.

PAL, R.; GOPINATH, C.; RAO, N. M.; BANERJEE, P.; KRISHNAMOORTH, V.; VENKATARAMANA, N. K.; TOTEY, S. Functional recovery after transplantation of bone marrow-derived human mesenchymal stromal cells in a rat model of spinal cord injury. Cytotherapy, Bangalore, v. 12, n. 6, p. 792-806, 2010.

PARK, W. B.; KIM, S. Y.; LEE, S. H.; KIM, H. W.; PARK, J. S.; HYUN, J. K. The effect of mesenchymal stem cell transplantation on the recovery of bladder and hindlimb function after spinal cord contusion in rats. BioMed Central Neuroscience, Korea, v. 11, n. 119, p. 119-130, 2010.

PITTENGER, M. F.; MACKAY, A. M.; BECK, S. C. J.; AISWAL, R. K.; DOUGLAS, R.; MOSCA, J. D.; MOORMAN, M. A.; SIMONETTI, D. W.; CRAIG, S.; MARSHAK, D. R. Multilineage potential of adult human mesenchymal stem cells. Science, Maryland, v. 284, n. 5411, p. 143-147, 1999.

PLOTNIKOV, A. N.; SHLAPAKOVA, I.; SZABOLCS, M. J.; DANILO JUNIOR, P.; LORELL, B. H.; POTAPOVA, I. A.; LU, Z.; ROSEN, A. B.; MATHIAS, R. T.; BRINK, P. R.; ROBINSON, R. B.; COHEN, I. S.; ROSEN, M. R. Xenografted adult human mesenchymal stem cells provide a platform for sustained biological pacemaker function in canine heart. Circulation, New York, v. 116, n. 7, p. 706-13, 2007.

RA, J. C.; SHIN, I. S.; KIM, S. H.; KANG, S. K.; KANG, B. C.; LEE, H. Y.; KIM, Y. J.; JO, J. Y.; YOON, E. J.; CHOI, H. J.; KWON, E. Safety of intravenous infusion of human adipose tissue-derived mesenchymal stem cells in animals and humans. Stem Cells and Development, Korea, v. 20, n. 8, p. 1297-1308, 2011.
REBELATTO, C. K.; AGUIAR, A. M.; MORETÃO, M. P.; SENEGAGLIA, A. C.; HANSEN, P.; BARCHIKI, F.; OLIVEIRA, J.; MARTINS, J.; KULIGOVSKI, C.; MANSUR, F.; CHRISTOFIS, A.; AMARAL, V. F.; BROFMAN, P. S.; GOLDENBERG, S.; NAKAO, L. S.; CORREA, A. Dissimilar differentiation of mesenchymal stem cells from bone marrow, umbilical cord blood, and adipose tissue. Experimental Biology and Medicine, Curitiba, v. 233, n. 7, p. 901-913, 2008.

ROET, K. C. D.; EGGERS, R.; VERHAAGEN, J. Noninvasive bioluminescence imaging of olfactory ensheathing glia and schwann cells following transplantation into the lesioned rat spinal cord. Cell Transplantation, Atlanta, v. 21, n. 9, p. 1853-1865, 2012.

RYAN, J. M.; BARRY, F. P.; MURPHY, J. M.; MAHON, B. P. Mesenchymal stem cells avoid allogeneic rejection. Journal of Inflammation, Ireland, v. 8, n. 2, p. 1-11, 2005.

SCHREPFER, S.; DEUSE, T.; REICHENSPURNER, H.; FISCHBEIN, M. P.; ROBBINS, R. C.; PELLETIER, M. P. Stem cell transplantation: the lung barrier. Transplantation Proceedings, Stanford, v. 39, n, 2, p. 573-576, 2007.

SOARES, M. B. P. Células-tronco adultas In: MORALES, M. M. Terapias avançadas: células-tronco, terapia gênica e nanotecnologia aplicada à saúde. São Paulo: Atheneu, 2006. cap. 3, p. 25-38.

SOUZA, A. S.; ESCOBAR, F. B.; DEL BEL, E. A. Influência do estreitamento do canal vertebral e do tempo para a descompressão na recuperação locomotora de ratos. Coluna/Columna, Ribeirão Preto, v. 8, n. 2, p. 117-126, 2009.

URDZIKOVA, L.; JENDELOVÁ, P.; GLOGAROVÁ, K.; BURIAN, M.; HÁJEK, M.; SYKOVÁ, E. Transplantation of bone marrow stem cells as well as mobilization by granulocyte-colony stimulating factor promotes recovery after spinal cord injury in rats. Journal of Neurotrauma, Czec Republic, v. 23, n. 9, p. 1379-1391, 2006.

VILLANOVA JUNIOR, J. A. Transplante de célulastronco derivadas do tecido adiposo em ratos submetidos à lesão medular compressiva, com e sem tratamento com corticoide. 2013. Tese (Doutorado em Ciências Veterinárias) - Universidade Federal do Paraná, Curitiba.

WANG, N.; LI, Q.; ZHANG, L.; LIN, H.; HU, J.; LI, D.; SHI, S.; CUI, S.; ZHOU, J.; JI, J.; WAN, J.; CAI, G.; CHEN, X. Mesenchymal stem cells attenuate peritonral injury through secretion of TSG-6. Plos One Journal, São Paulo, v. 7, n. 8, p. 1-17, 2012. 